\title{
THE ABORIGINAL EMBASSY: AN ACCOUNT OF THE PROTESTS OF 1972
}

\author{
S. Robinson
}

By 1972, Australian Aboriginal people had developed a form of political consciousness which embraced the idea of land rights, and had for the most part adopted protest as their means of political expression. The Aboriginal Embassy of 1972 was the result of a decade of debate within the Aboriginal community over means and goals. It involved both the adaptation of exogenous notions of Black Power, and the political expression of a traditional awareness of original dispossession. ${ }^{1}$ It was on the lawns of the Federal Parliament House that these issues were aired in the public arena during the nine-month existence of the embassy. The events of 1972, a story of both tumultuous violence and calm restraint through symbolic response, culminated in the relative success of this seminal protest. The return of land was placed on the political agenda of the major parties; the embassy achieved a semi-legendary status and inspired Aboriginal activists over the following years.

There exist a variety of accounts, in Aboriginal oral history, and in the few written mentions of this significant event, of the inspiration for the embassy. Kevin Gilbert, Charles Perkins, Burnum Burnum (Harry Penrith), and Michael Anderson played a part in these different versions. It is agreed by all participants, however, that the embassy was conceived as a direct response to the Australia Day Statement by Prime Minister McMahon on 26 January 1972.

The statement epitomised the Liberal-Country Party coalition's policy of a diluted assimilationism which sought to quash the 'separateness' of Aboriginal people, ${ }^{2}$ and make them part of mainstream Australian society. The Australia Day statement began with the assertion that the government acknowledged 'the deep affinity between Aboriginal people and the land' and announced that new policies on 'land holdings on Aboriginal reserves and elsewhere' had been formulated. ${ }^{3}$ A five-point plan followed. Firstly, the statement promised assistance to groups and individuals 'to hold effective and respected places within one Australian society' whilst maintaining culture and traditions 'within the diverse culture of Australian society'. ${ }^{4}$ Secondly, McMahon emphasised that although assimilation was, after changes to that policy in the $1960 \mathrm{~s}$, a matter of 'choice', the idea of 'separate development as a long term aim is utterly alien to these objectives'.

Scott Robinson died tragically between the time of writing this article and its publication. He had begun study towards a Ph.D thesis on the history of the Aboriginal people of north coastal NSW. He was a promising and deeply committed historian, as this, his first and last article, demonstrates.

1 This was, in addition, the extension of a tradition of ownership of land by Aboriginal people in the eastern States in the nineteenth century, and its revocation which brought double dispossession (see Goodall 1990; Morris 1985; Reynolds 1990). The tradition of ownership was maintained through its cultural transmission, and also through occasional political references such as the Ferguson/Patten campaign for civil rights in the 1930s, which held rights to land as a secondary objective.

2 Hasluck 1988, p. 22.

3 . McMahon $\div 1972$.

4 ibid., p. 9. 


\section{ABORIGINAL HISTORY 1994 18:1}

The statement went on to suggest that the government take action to ameliorate education, employment and housing, and remove what it referred to as 'special disabilities' before the law. McMahon unashamedly stated that 'good progress is being made' in improving health standards in Aboriginal Australia. ${ }^{5}$

The remainder of the statement was a response to the burgeoning demand for land rights by Aboriginal people throughout Australia. It was also a rebuff to the Council for Aboriginal Affairs, an advisory body whose members (Barrie Dexter, H.C. Coombs and W.E.H. Stanner) had for some time urged acceptance of the demand for land rights despite the intransigence of successive ministers for the Interior and Environment, Aborigines and the Arts. McMahon acknowledged the desire of Aboriginal people to have their affinity with the land recognised by law', but then proceeded to enumerate the constraints which would apply to Aboriginal access to land. There were to be no land rights in a form recognisable by the Aboriginal activists of the time and their supporters, as this would 'lead to uncertainties and possible challenge in relation to land titles in Australia which are presently unquestioned and secure. ${ }^{6}$

The statement announced the introduction of 'general purpose leases' in the Northern Territory, where fifty year leasehold was to be granted, provided that 'reasonable economic and social use of the land' was made by recipients. Land was not to be available on existing missions, reserves or crown land, and land outside the reserves was to be purchased by the government as it became available. ${ }^{7}$ Finally, McMahon made specific reference to the Yirrkala people's opposition to the Nabalco mining venture, stating that the mine at Gove was 'in the national interest'. 8

Among those Australians who heard the Australia Day statement on the national media were the central core of young Aboriginal activists from the eastern States, gathered in Redfern. These Aboriginal people had a close association with politics through the demonstrations of the preceding years, and through the social connections of the Redfern community.

For some months, Chicka Dixon had been hosting discussion nights at his home, bringing together activists such as Gary Foley, Michael Anderson, Paul Coe, John Newfong, Billy Craigie and Gordon Briscoe. At other times this same group, with their origins in rural Australia and their meeting place in the city, would gather at the pool tables in the Clifton Hill and Empress hotels. The concept of a symbolic protest in Canberra may have been the brainchild of Charles Perkins, ${ }^{9}$ Kevin Gilbert, ${ }^{10}$ Burnum Burnum (who suggested a hunger strike to Michael Anderson some months previously) ${ }^{11}$ or activists associated with the newly-established Aboriginal Medical Service. ${ }^{12}$ It is accepted, however, that Gilbert took the organisational steps by calling together the first ambassadors, and by approaching the Communist Party of Australia for funding.

The car which left Sydney on the night of 25 January was driven by the Tribune's photographer, Noel Hazzard. Bertie Williams was dragged from his bed to join Billie

5 ibid., p. 7. At the time, infant mortality and the incidence of disease affected Aborigines at a disproportionately high rate.

ibid., p. 9.

ibid., pp. 10-12.

ibid., p. 12.

Read 1990 , p. 129.

10 Gilbert 1973, p. 28; interview, 1 May 1991.

11 Michael Anderson (from northern NSW), interview, 28 August and 10 November 1991.

12 Billy Craigie (from the far north coast of NSW), interviewed in 'True Stories', ABC television documentary, 2 August 1992. 


\section{THE ABORIGINAL EMBASSY}

Craigie, Gary Williams and Michael Anderson in their hurried journey to Canberra. ${ }^{13}$ Hazzard assisted the protesters by making contact with a local academic, and fellow member of the CPA. While Bertie Williams suggested the idea of calling the encampment an 'embassy', the group was provided with a beach umbrella and materials for placards. ${ }^{14}$ They erected the umbrella on the lawns of the Federal Parliament House in the early hours of the morning, identifying themselves with a sign reading 'Aboriginal Embassy'.

The new presence on the lawns did not pass unnoticed. The Commonwealth police asked the protesters what they were doing outside Parliament House. 'We're having a protest', was the reply. When told that the protest would continue until the government granted land rights to the Aboriginal people, the police remarked that 'that could be forever'. ${ }^{15}$ Nevertheless, the shivering Aborigines remained for the duration of the night.

Canberra, and the rest of the nation, awoke the next morning to the news of the embassy. Michael Anderson, whose name is to a certain extent synonymous with the early phase of the embassy, made the first statements from the lawns. He told the press:

As soon as they start tearing up Arnhem Land we're going to start tearing up

bits of Australia ... the land was taken from us by force ... we shouldn't have

to lease it ... our spiritual beliefs are connected with the land. ${ }^{16}$

While other Aboriginal protesters (including Bobbi Sykes and Bruce McGuiness) began to arrive, a second statement was issued from the lawns of Parliament House. It demanded retraction of the Australia Day statement and compensation for stolen lands, and warned the government that the embassy would stay until these demands were met. The focus of these early comments by the embassy drew attention to an occupancy of the continent then acknowledged as 30000 years old, and demanded recompense.

The ideology expressed at this stage was vague in detail, a slogan rather than a program. Some supporters and members of the public were left to wonder what in fact was meant by 'land rights'. It was clear, however, that a form of indigenous tenure other than that permitted under the McMahon statement was called for by a group whose interest encompassed both the more traditional areas of Australia and their own 'country' in the eastern States. A broad desire for the return of an economic base under freehold title, and compensation to make that base workable, underlay these early statements.

In addition to public statements, the embassy made a media impact through its very existence, and through conscious use of symbolic protest. The encampment was an Aboriginal twist on the larrikin sense of humour which throws rough-hewn insolence in the direction of established Australian authority. As Dr Roberta Sykes reflected, it was only a wag's act to put it up anyway, in the beginning'. ${ }^{17}$ In addition, it was a display of symbolism at several levels, being simultaneously a comment on living conditions in Aboriginal Australia, on the question of land ownership (of this particular piece of ground as well as other parts of Australia), on the relative status of indigenous people in a city dotted with embassies, and on the avenues of protest open to the otherwise (often) silent minorities in Australian society. Sykes wrote later that 'to occupy a building similar in structure to those used by the oppressive bureaucratic machine would have been to alienate the protest from the level of the people. ${ }^{18}$ Gary Foley thought that they declared it the

13 Bertie Williams died in 1974. It is likely that Gary Williams was also present. (Interviews with Noel Hazzard, Michael Anderson and Gary Foley, 1991.)

14 Michael Anderson, interview, 28 August and 10 November 1991.

15 ibid.

16 Canberra Times, 26 January 1972.

17 Dr Roberta B. Sykes (from north Queensland), interview, 18 October 1991.

18 Turner 1975 , pp. 23-4. 
Aboriginal Embassy' because 'Aborigines are treated like aliens in their own land', and 'unlike embassies on Red Hill in really flash surroundings', the protest was to be in the public arena, 'under the noses' of the parliamentarians. ${ }^{19}$

Tourists and visitors began to arrive at the embassy, while non-Aboriginal support became apparent. The Australian Council of Trade Unions made a statement in support of the Yirrkala people. The National Council of Aboriginal and Torres Strait Island Women met at the Australian National University on 28 January, and although the campus was virtually empty of students at this time of year, a group of residents associated with the anti-apartheid campaign made contact with the embassy, and began the important contribution made by student supporters. ${ }^{20}$

A new placard appeared on the lawns in the last days of January; it read 'which do you choose - land rights or bloodshed?'. Its identification of the struggle with the rhetoric of violence and the clenched first salute of Black Power made clear the tension between symbolic, non-violent, creative protest, and more belligerent means. This tension remained unresolved, but it was through the former approach that the embassy made its presence felt for the six months which followed.

In January, the lawns of Parliament House had been virtually taken over by the Aboriginal protesters. For the first time since the opening of the building in 1927 (when an 'inadequately clad' Aborigine was removed from the ceremony) ${ }^{21}$ a permanent camp existed on the lawns. This posed administrative problems for the government, and especially for Ralph Hunt as Minister for the Interior. A twenty-four hour police surveillance was instituted on 30 January. ${ }^{22}$ The only applicable legislation, however, was the Gaming and Betting Ordinance, s. 19(a), which imposed a forty dollar fine for loitering in a public place. Minor incidents such, as the question of mowing the lawn were easily settled - the protesters offered to mow if themselves, and were only mildly disrupted when drenched by the groundsmen's sprinklers.

Anderson made a more comprehensive statement of demands in early February. This five-point plan addressed Aboriginal ownership of all existing reserves and settlements (including rights to mineral deposits), ownership of land in the capital cities (including mineral rights), preservation of all sacred sites in all parts of the continent, six million dollars in compensation, and full rights of statehood for the Northern Territory. At the same time, Anderson named a 'ministry', including a Minister for the Arts, Environment and Caucasian Affairs. ${ }^{23}$ These demands were an expression of a program of land rights for all Aboriginal people; they were both serious demands for redress, and an example of the use made by the embassy of uncompromising public relations which created unprecedented media attention for Aboriginal activism and its cause.

It was at this point that Ralph Hunt first suggested that action be taken to remove the embassy. An interdepartmental committee recommended that the existing Gaming and Betting Ordinance not be applied, and that new legislation be created under the Commonwealth Lands Ordinance.

19 Gary Foley (from Cangai, on the north coast of NSW), interview, 7 June 1991.

20 Jack Waterford (white supporter), interview, 30 July 1991.

21 Clark 1980, p. 220.

22 Canberra Times, 31 January 1972. It should be noted that relations between the Commonwealth police and the Aborigines were cordial in these months, often involving cups of tea and conversation over the campfire.

23 Australian, 3 February 1972. (These terms were later dropped as being 'too much like white bureaucracy'.) 


\section{THE ABORIGINAL EMBASSY}

Support for the embassy began to increase. A group of Aboriginal people from Yirrkala, and from Elcho, Bathurst and Melville islands visited Canberra. Their number included Galarrwuy Yunupingu and Wali Wunungmurra, and their presence enriched the embassy by lending a pan-Aboriginal appearance to the protest. ${ }^{24}$ Australian Labor Party (ALP) leader Gough Whitlam and local member Kep Enderby ${ }^{25}$ visited the tents on 8 February, when Whitlam gave a partial endorsement to the embassy's five-point plan. 26 Land rights were to be granted under Labor, and although this was a non-specific response to a relatively non-specific demand, ${ }^{27}$ the promise to grant statehood to the Northern Territory and abolish remaining discriminatory laws in the States was unequivocal.

In addition to large numbers of tourists, visitors to the embassy included Soviet diplomats, a representative from the Canadian Indian Claims Commission, and a cadre from the Irish Republican Army who donated a linen handkerchief to the cause. ${ }^{28}$ International media coverage included articles on the embassy in the London Times, the Guardian, Time magazine, Le Figaro, Le Monde, and the New York Times. ${ }^{29}$

The most important group of supporters was, however, the student body of the Australian National University (ANU). The facilities of the Student Representative Council were made available, and there was extensive social mingling between Aboriginal people and students who had become politicised by involvement in the movements against conscription, Australian involvement in the Vietnam War, and the recent Springbok tour. As Richard Refshauge indicated, land rights was an issue which 'demanded' attention. Support was provided in a manner which recognised that 'Aborigines were not going to allow their decision-making or the way they were perceived infiltrated'. 30 During the demonstrations of 1972, a strong and supportive student presence was apparent.

The government and associated bureaucracy remained at odds during this period. The Council for Aboriginal Affairs, ${ }^{31}$ although regarding the Australia Day statement as 'a very small step forward' on land rights, openly criticised the government's stance. ${ }^{32}$ Barrie Dexter, the council's executive member, reflected that:

From the outset in the Council and Office we felt sympathy and admiration for the 'Embassy' members, who had demonstrated a perceptive understanding of the real meaning of the government's policy, and devised a most ingenious

24 Andrea Collins, letter dated September 1991 (ATSIC regional office, Nhulunbuy). PanAboriginal basis for the protest, however, was challenged due to the questionable dichotomy between traditional and less-traditional people, brought about by the Protection era and reproduced by white Australian racism.

25 Now Mr Justice Enderby.

26 Australian, 9 February 1972.

27 Other comments by Whitlam make it clear that his vision was one of Australia-wide return of land. His reference was consistently to the International Labour Organisation's convention no. 107, which did not distinguish between more traditional groups and Aborigines in the eastern States and Western Australia.

28 Tribune, 30 May 1972.

29 See, for instance, New York Times, 8 March 1972.

30 Richard Refshauge (then SRC President), interview, 18 April 1991; Allan Gould (student supporter), interview, 2 May 1991.

31 Since 1967, the government's 'think tank' on Aboriginal Affairs. Its three members W.E.H. Stanner, H.C. Coombs and Barrie Dexter - were attached to the Prime Minister's Department and in its relationship with the minister the council held advisory powers only. See W.E.H. Stanner's letter in the Canberra Times, 8 February 1972. 


\section{ABORIGINAL HISTORY 1994 18:1}

means of getting across to the government the message we had been trying to impart. ${ }^{33}$

Dexter considered that the council viewed land rights as an 'Australia wide' concern, and when Coombs visited the tents in February John Newfong announced that he had expressed 'complete sympathy' with the demands of the protest. ${ }^{34}$ The council, however, remained frustrated by the government at all turns.

The embassy became an issue in parliamentary debate on the first day of sitting on 23 February. While Howson, Minister for the Environment, the Arts and Aborigines, insisted that the concept of land rights was 'alien to native thought', Ralph Hunt (Minister for the Interior) made the first mention of 'an ordinance to ensure that Parliament House is reserved for its purpose ... not a place where people can camp indefinitely'. ${ }^{35}$ Hunt acknowledged that the demonstration was peaceful and 'quiet', but later in the day criticised the involvement of the socialist left who, he stated, would use Aboriginal people as a 'political football' in the interest of 'attacking our present order of society'. ${ }^{36}$ Labor members condemned the government's statements, and Gordon Bryant called the embassy 'one of the most original demonstrations we have for some time in any political field'. Gough Whitlam called for a commission to consider land rights 'for the whole Commonwealth ... not just the Northern Territory: ${ }^{37}$ A number of ALP members signed a petition promising to physically defend the tents.

The response from the embassy to the threat of a removal of the tents was to promise, in the words of Denis Walker, a 'bloody fight' if an attempt was made to disperse the protest. ${ }^{38}$ Others, who adhered more to the non-violent, symbolic approach of the embassy rather than the street-fighting call of the (Australian) Black Panthers, were equally determined to remain in situ on the lawns until their demands were met.

Thus began several months of continued protest, threats of removal by Hunt, and further publicity for the embassy. Hunt wrote to the Prime Minister on 24 March, 'indicating intention to amend ordinance'. ${ }^{39}$ On the lawns, a constantly changing and fluctuating population of Aboriginal people from throughout Australia remained encamped under the red, black and green flag of internattional Black unity. ${ }^{40}$ The floating population usually peaked at weekends, when carloads of Aboriginal people travelled from Sydney. Chicka Dixon organised much of the transport, while prominent activists such as Gary Foley, Bruce McGuiness, Paul Coe and Sam Watson arrived at the end of each week. News rapidly spread throughout Aboriginal Australia, and the fame of the protest continued to increase.

Hunt, it was widely assumed, would delay taking action until after the potentially embarrassing South-East Asia Treaty Organization conference in Canberra on 27 June. During this extended reprieve, a nation-wide protest for Aboriginal land rights was held under the banner Ningla-A-Na (an Arrernte word meaning 'hungry for our land'). Conducted on National Aborigines Day, marches in most capital cities occurred without violent confrontation, despite comments such as Foley's that the time of white pacifism is

33 Dexter n.d.

34 Camberra News, 18 February 1972.

35 Australia, House of Representatives 1972, Debates, vol. HR76, pp. 108, 304.

36 ibid., pp. 131, 135. ASIO had already warned Hunt and other ministers of what its personnel considered a threat to their safety by Aboriginal activists (see Howson 1984, pp. 819, 829).

37 Australia, House of Representatives 1972, Debates, vol. HR76, pp. 128, 135.

38 Canberra Times, 27 March 1972.

39 Department of the Interior, Aide Memoire, 27 June 1972 (in possession of Ralph Hunt).

40 The black, red and yellow Aboriginal flag, designed in 1971, arrived at the embassy in July. 


\section{THE ABORIGINAL EMBASSY}

gone'. ${ }^{41}$ The Ningla-A-Na protest centred on the demand for land rights, and on the prevention of the Nabalco mining operation at Gove. In addition, the marches made it clear that the Australia Day statement was viewed as empty rhetoric by the Aboriginal activists and their supporters.

Hunt finally took action on 17 July, when Inspector J. Johnson of the Commonwealth police handed a draft of the new ordinance to Ambrose Golden-Brown at the embassy. The draft made clear new penalties for camping in a public place such as the lawns of Parliament House. 42 While Richard Refshauge, President of the ANU Students' Representative Council, offered to assist the demonstration through a 'passive stand', a statement was issued by the embassy to the effect that the Aboriginal protesters would undertake a 'sandbag defence'. ${ }^{43}$

The halcyon days of protest at the embassy ended on 20 July. For six months, the embassy had been a creative, non-violent direct action. whose demands directly contradicted the ideology of the status quo. Although there had been allusions to the sort of power which emanates from the barrel of a gun, the protest had been an entirely non-violent display of political commitment. The events which followed were the result of almost ten years of Aboriginal protest over the right to their land, and five months of debate within the government over the wisdom of using force to disperse a nationally (and internationally) embarrassing demonstration.

Hunt's final promise on 18 July was that there would be two weeks' grace before the implementation of the new law. Fearing police action was imminent, student supporters established a vigil the next day. ${ }^{44}$ Nevertheless, the intervention of the police came with an element of 'surprise'. ${ }^{45}$ Pat Eatock, an Aboriginal participant in the embassy and also employed at the government printer, overheard police requesting a copy of the new gazette on the morning of the twentieth ('get us the first one ... we're waiting to move on it'). ${ }^{46}$ As the two-way radio link to the university and the university switchboard were apparently jammed, Eatock left work and phoned several student residences. By ten o'clock there were thirty people at the embassy, and by the time student supporter Steven Padgham had drawn more students away from their lectures the number had increased to seventy.

At half past ten, Inspector Osborne led 150 police toward the tents. The protesters faced a body which marched as 'a paramilitary force' from behind Parliament House. ${ }^{47}$

The ensuing fracas occurred between police supposedly acting with the legitimate authority of the state and demonstrators who regarded that authority as bogus. To the demonstrators, the state's actions represented an affront to the right to peaceful protest against injustice which could be redressed only by 'land rights ... now!".48 Osborne made several announcements over the megaphone, warning the protesters to move away from the tents, and advising them that if you fail to move you may be arrested for obstructing police'. ${ }^{49}$ The protesters linked arms and sang 'we shall overcome' as the police advanced towards them.

41 Tribune, July 1972.

42 Canberra Times, 18 July 1972.

43 ibid.

44 Canberra News, 19 July 1972.

45 Gary Foley, interview, 7 June 1991.

46 Pat Eatock (from Boguntungan in Queensland, then resident in Canberra), interview, 17 July 1991.

47 Di Riddell (then secretary of the ANU SRC), interview, 17 August 1991.

48 Ningla-A-Na, film directed by Alessandro Cavadini, 1972.

49 Canberra News, 20 July 1972. 
An 'all-out, all-in' brawl followed. ${ }^{50}$ There was no doubt among the participants that the police commenced the violence, and some officers were seen to remove their badges before attacking the protesters. ${ }^{51}$ Peter Burns, a local resident, remembered how he linked arms with a woman of fifty who 'copped a boot in the groin' from the police. ${ }^{52}$ Gordon Bryant, fulfilling his pledge to defend the embassy, was seen pulling a policeman away from a protester. ${ }^{53}$ As Aborigines and white supporters grappled with police, a number were led away:

The paddy wagon ... was parked up on the gravel. The coppers opened the back ... just threw them in. 54

The tents were ripped from the lawns and taken away in a police vehicle. Eight people, including five Aborigines, were arrested, while 'almost every demonstrator ringing the tent was injured or bruised in some way'. ${ }^{55}$ Paul Coe was admitted to hospital, and Gary Foley was also injured. ${ }^{56}$ According to Bobbi Sykes, most of the eight police injured suffered broken knuckles and teeth marks on their hands. ${ }^{57}$

Reactions by the various parties involved, and by the public, were varied. The media gave the event precedence over the national petrol strike, and this at once raised issues of civil liberties and Aboriginal land rights. Hunt denounced Bryant and Enderby for participating, and blamed the incident on people who had come from outside to stir up trouble' ${ }^{58}$ Whitlam sarcastically congratulated the government on:

the despatch it showed against these Aborigines in contrast to its impotence in the face of travel swindlers, international gangsters and fascist bombers and tax racketeers. 59

Barrie Dexter considered the first removal a 'tragedy', which had put an end to 'a courageous Aboriginal initiative' ${ }^{60}$ Coombs alse expressed regret at the government's action, and suggested that 'there remain avenues for protest which I hope they (Aborigines) will continue to use ${ }^{t}{ }^{61}$

Those more closely involved considered the first removal to be a 'token fight' which left 'feeling running very high'. ${ }^{62}$ Aboriginal participants were particularly aware of the public anger generated by the actions of the police - Gordon Briscoe reflected that 'The violence as it was portrayed on TV ... was on a par with the Vietnam images, on a par with the anti-apartheid images'.63

The embassy, although uprooted from its campsite, continued to exist in the determination of Aboriginal people, now billeted in student houses and the university buildings in Childers Street. Protest was planned over the removal, and over the demand for land rights which it had come to represent.

50 Chris Swindbank (student supporter), interview, 2 May 1991.

51 Review, 29 July 1972.

52 Peter Bums (Canberra resident and white supporter), interview, 23 August 1991.

53 Western Australian, 21 July 1972.

54 Peter Burns, interview, 23 August 1991.

Tribune, 25 July 1972; Canberra News, 20 July 1972.

Western Australian, 21 July 1972.

Review, 29 July 1972.

Department of the Interior, press release, 20 July 1972.

McNally 1973 , p. 86.

Dexter n.d.

ibid.

Jack Waterford, interview, 30 July 1991.

63 Gordon Briscoe (from central Australia), interview, 22 May 1991. 


\section{THE:ABORIGINAL EMBASSY}

On 21 July, student supporters enlisted the aid of Terry Higgins ${ }^{64}$ in making a legal challenge to the ordinance. A Supreme Court injunction was sought by Ambrose GoldenBrown, Billy Harrison, Pat Eatock, and Allan Sharpley in the hope of preventing any further removal of tents from the lawns of Parliament House. ${ }^{65}$ On the same day, Senator Murphy announced an ALP resolution against the ordinance.

A march through the streets of Canberra was organised on the twenty-second. Later. that day a meeting took place between Superintendent Rochford and Inspector Osborne of the Commonwealth police, and Dexter, Refshauge, Briscoe, Sykes, Eatock, Paul Coe, Les Watson and Gary Williams. Although there was some recognition that the ordinance had been passed with 'haste ... and a bit of criticism', ${ }^{66}$ the meeting failed to produce anything but confirmation of the polarised attitudes of the opposing parties. The Aboriginal representatives asked why the police had acted as 'mindless people' who refused to 'look beyond the letter of the law to the real human aspects of the situation', 67 and reaffirmed their right and intention to demonstrate for the return of their land in front of Parliament House.

Warnings of physical resistance were issued by the embassy-in-exile on the twentysecond. Dennis Walker observed that violence was 'not only likely, but bloody well necessary. We're just not going to stand silently and watch our people beaten up. 68 Bobbi Sykes described the feelings of the demonstrators, including those who eschewed violence, as follows:

We couldn't allow ourselves to be placed in a position which would even appear we were compromising either ourselves or our people ... reserve blacks saw it [the embassy] as the only ray of light to appear on their darkened horizons for many years. Most urban blacks regarded it as the first positive step towards equality so far. ${ }^{69}$

Sunday, 23 July 1972, was another day of violent confrontation between Aboriginal people and their supporters (who numbered some 200), and the police. The protest, which included a number of older members of various Aboriginal communities ${ }^{70}$ marched through the city and across Commonwealth Avenue Bridge to restore the tents to the lawns. Aboriginal people, students, unionists and other supporters sat on the road in front of Parliament House, while others linked arms around the tent and sang 'we shall overcome', and chanted slogans including 'the whole world's watching', 'land rights now', 'free Black Australia', and 'Stop Nabalco'. Paul Coe reminded white supporters that 'What is happening here today to black men and women is surely going to happen to white men and women ... What will they [the government] do to you tomorrow? ${ }^{71}$

The demonstration formed itself into a number of circles around the tents. Police selected Bobbi Sykes from the crowd and asked her to tell the demonstration to disperse. She refused. ${ }^{72}$ A figure appeared at a window in Parliament House, and word spread that it was Ralph Hunt taking a look at the proceedings. A chant started up, rhyming slang

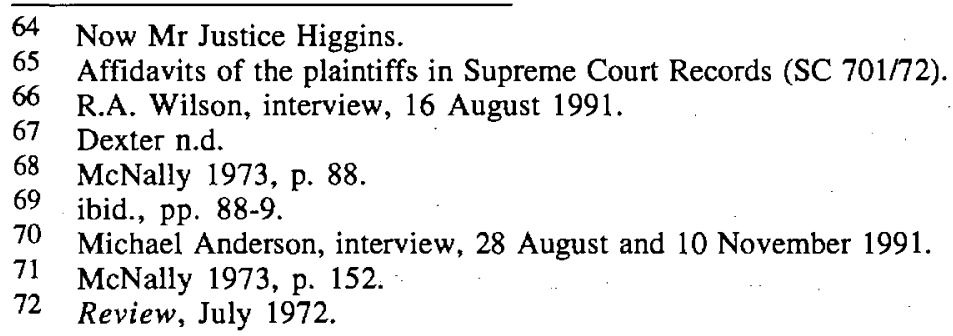


mocking the minister's surname, which 'infuriated' the police. ${ }^{73}$ While the protest in general 'cheerfully and loudly told the police to fuck off, ${ }^{74}$ there was at the same time a clear call over the protesters' megaphone: 'we don't want violence either'. ${ }^{75}$

Preceded by the sound of their boots crunching on the gravel, some 360 police emerged from behind Parliament House. Another chant started, this time the Sieg Heil of Nazism, in parody of this manifestation of the power of the state. ${ }^{76}$ Particularly threatening was the presence of NSW police uniforms amongst the approaching troop. ${ }^{77}$

The violence which followed was even more intense than that of the previous Thursday. Cavadini's film of the event showed the full extent of the tumultuous brawl on the lawns, detailing incidents such as the souveniring of a police badge by an Aboriginal protester and incitements over the megaphone as the violence escalated ('everyone in uniform should have their guts blown out'). ${ }^{78}$ Michael Anderson remembered how:

One big blond headed bloke pulled an old woman to the ground ... as soon as we saw that we saw red ... we clobbered him.

By the end of the second removal, nine protesters had been taken for treatment by Pat Sorby at the ANU Health Service. Eight Aboriginal people (including Isabel Coe, Michael Anderson and Gary Williams) and ten white supporters were arrested, and five police treated for bites, cuts and abrasions. ${ }^{79}$ Almost immediately, it was announced that another reerection of the tents would take place on the following Sunday, and one Aboriginal protester left the lawns with the comment: 'next time we come with fuckin' guns', ${ }^{80}$

The number of arrests bore no relationship to the magnitude of the violence, and it was the view of many participants that it was surprising that no-one was killed. Chicka Dixon called it the most violent event he had ever witnessed. ${ }^{81}$ Pat O'Shane remembered a 'major public outcry' and a feeling of outrage that 'an innocuous group of people should evince such a violent action against it. ${ }^{182}$ Gary Foley remembered the media value of the protest (for good or ill) as lying with its being 'one of the most violent confrontations in the history of Canberra'. ${ }^{83}$

After two removals of the embassy, the essential issues of land rights and the right to mount such symbolic, creative and non-violent protest, remained unresolved. The tension between the embassy and all it stood for, and the forces of authority, had not diminished since 20 July. The question loomed: was there to be a third, even larger and more violent, protest in front of the seat of government?

On the afternoon of the twenty-third, Aboriginal protesters met at the ANU bar to plan their next move. Those present included Johnny Coe, Bob Maza, Denis Walker, Chicka Dixon and Gary Foley. Consensus had established that another re-erection would take place, and the discussion thus centred on tactics. There was suggestion of 'a few molotov

Peter Burns, interview, 23 August 1991.

Jack Waterford, interview, 30 July 1991.

Ningla-A-Na, directed by Allesandro Cavadini, 1972.

ibid.

Various informants; cf. Ron Dillon's (former Commonwealth police officer) view that police from interstate were not used during the suppression of the embassy (interview, 18 August 1991).

Ningla-A-Na, directed by Allessandro Cavadini, 1972.

Canberra Times, 24 July 1972.

Peter Burns, interview, 23 August 1991.

Chicka Dixon (a slightly older activist from western NSW, then resident in Sydney), interview, 2 July 1991.

Pat O'Shane (from north Queensland), interview, 22 October 1991.

Gary Foley, interview, 7 June 1991. 
cocktails around town' as payback for the brutality of that morning; ${ }^{84}$ Denis Walker proposed appeal to post-colonial African nations and the People's Republic of China, and also suggested that 'if they take the embassy we take something of theirs ... preferably property rather than people. ${ }^{185}$ When asked for comment, Chicka Dixon merely shook his head. On the twenty-sixth, Pat Eatock warned that there was every possibility that the planned re-erection would turn into 'Australia's Sharpeville'. 86

Meanwhile, on the twenty-fifth, Mr Justice Fox adjourned a writ seeking declaration of the invalidity of the ordinance. He found that section twelve of the Seat of Government Act, which provided for the notice and availability of new ordinances, was an 'unsatisfactory piece of legislation' ${ }^{87}$ Although the application for permission to return the embassy to the lawns was rejected, the protest had again embarrassed the government.

The government and its ministers were aware of the threat of a major incident but, in the days leading up to $30 \mathrm{July}$, continued in a blundering policy of prevarication. McMahon appeared in the media as irretrievably paternalistic and out of touch with the political realities of the situation - he stated his chief interest as 'my people, the Aborigines'. 88 The Prime Minister's only response to the impending demonstration was to tell Howson and Hunt to co-operate on the matter and seek a negotiated solution, something which neither minister achieved. ${ }^{89}$

Attempts at intercession to prevent further violence were made by a number of individuals. Richard Refshauge and the Reverend Garnsey, ANU Chaplain, suggested to J.O. Ballard (Deputy Secretary of the Department of the Interior), that the tents be 'reestablished and then pulled down again' to avoid confrontation, but the proposal was rejected. ${ }^{90}$ Paul Coe asked Hal Wootten, President of the Aboriginal Legal Service, to intervene, but Wootten was uncertain what, if anything, he could do in the circumstances. 91

The three members of the Council for Aboriginal Affairs, then in Darwin for a joint Federal and State meeting, advised the minister to negotiate. Howson, however, was opposed even to Hunt's proposal for a 'club' as a permanent meeting place for Aboriginal people in the national capital. ${ }^{92}$ Howson continued to refuse to negotiate with 'unrepresentative militants', while Hunt informed a meeting of police and embassy representatives (including Michael Anderson, Billie Craigie, Tiger Bayles, Margaret Lawrie and Pat Eatock) that 'the tent embassy was not on and could not be re-erected'.$^{93}$

84 Gary Foley, in Ningla-A-Na, directed by Alessandro Cavadini, 1972.

85 ibid.

86 Canberra Times, 27 July 1972.

87 Australia, House of Representatives 1972, Debates, vol. HR79, p.14.

88 McNally 1973 , p. 103.

89 Howson noted in his diary only that ASIO considered that Black militancy was experiencing problems with funding and popularity (Howson 1984, p. 889).

90 J.O. Ballard to minister's office, departmental document dated 24 July 1972 (in possession of Ralph Hunt).

91 The Hon. Hal Wootten AC, QC, personal recollections of the Aboriginal Embassy, 23 November 1992 (in possession of the author).

92 Dexter n.d. The proposal for a permanent meeting place had been rejected by the embassy some months earlier; it was appropriated and turned into a demand for a 'people's place' with the status of an embassy by Pat Eatock, Geraldine Briggs, Shirley Smith, Denis Walker and others on 26 July 1972 (letter to Howson from Aboriginal delegation dated 26 July).

Ballard to Hunt, Department of Interior document dated 27 July (in possession of Ralph Hunt). This document also mentioned the possibility of 'permitting' a tent to be put up, 'the 


\section{ABORIGINAL HISTORY 1994 18:1}

While Whitlam urged restraint, ${ }^{94}$ and Eatock telegrammed McMahon warning of 'a national crisis including bloodshed and possible death', 95 the disarray of the policy-makers reached a peak. Howson refused to co-operate with Coombs, ${ }^{96}$ or with Hunt, and preferred to heed the advice of Queensland Premier Joh Bjelke-Petersen to 'stand firm'. 97 While the embassy continued to demand the dropping of the charges laid at the previous demonstrations, re-erection of the tents and 'subsequent removal to a temporary representation centre' with full diplomatic status, McMahon vetoed any plan for a 'club' and was supported in this by Howson. ${ }^{98}$ All that was offered was a meeting of the State and Territory Advisory Committee, Howson's pet project, in August. ${ }^{99}$

On the Saturday night, R.A. Wilson announced his hope that there would be no violence, but promised that the law would be 'upheld'. Busloads of Aborigines were en route to Canberra from throughout Australia, many carrying warnings of 'bloodshed' (and some opposition to protest action) from the elders of their communities. This admonition was recalled by Kath Walker, ${ }^{100}$ who believed that on this occasion the elders felt that they would 'rather lose the land than lose the children'. ${ }^{101}$ At this stage Eatock, Foley, Anderson, Sykes, Dixon, Paul Coe, the Bellear brothers, and other Aboriginal protesters were struggling with the task of organising what could have been a bloodbath. Eatock remembered that 'people had reached the stage where they were prepared to die for the issue'. 102

On the overcast winter's Sunday of 30 July, Wootten made a final attempt to intercede, asking Wilson to delay police action and let the interstate Aboriginal protesters make their symbolic point before they returned home. No guarantee, however, was extracted from the police. ${ }^{103}$

The demonstration commenced at the university later in the morning. Aboriginal people formed groups according to their home State, and Aboriginal marshals walked the length of the rallying ground confiscating knives and other weapons ('you'll get it back later'). ${ }^{104}$ The demonstration then proceeded to Parliament House. Participants recalled the huge crowd (estimated at two thousand Aboriginal people and supporters, and a thousand tourists and onlookers). As Michael Anderson put it, 'I never saw so many people in my life'; 105 the sheer weight of numbers made it 'quite obvious that people were going to get hurt' if either the police or the protesters adopted violent tactics. ${ }^{106}$

police waiting until the demonstrators disperse before taking it down', but discussion of the proposal was deferred.

Sydney Morning Herald, 29 July 1972.

95 Canberra Times, 28 July 1972.

96 And in fact denied him a seat on the official plane returning to Canberra (see Coombs 1978 , p. 17).

97 Howson 1984 , p. 891.

98 Hunt and McMahon offered Newfong a club as a 'more permanent and dignified presence' in Canberra in May, an offer rejected by John Newfong in negotiations (Hunt n.d.).

99 Dexter n.d. (Cabinet minutes remain unavailable at the time of writing).

100 The late poet, and elder of the Nunukal people.

101 Oodgeroo Nunukal (Kath Walker), interview, 23 October 1991.

102 Pat Eatock, interview, 17 July 1991.

103 Hal Wootten, personal recollections of the Aboriginal Embassy, 23 November 1992 (in possession of the author). (See also Aboriginal Legal Service annual report, 1971-72, p. 9).

104 Pat Eatock, interview, 17 July 1991; Jack Waterford, interview, 30 July 1991.

105 Michael Anderson, interview, 28 August and 10 November 1991.

106 Gary Foley, interview, 7 June 1991. 


\section{THE ABORIGINAL EMBASSY}

Three circles were formed around the tent. Indicating the expectation of violence, twenty 'guards' were arranged between each of the circles, whose purpose was to place themselves between the protesters and the police. ${ }^{107}$ To the surprise of the demonstrators, the police seemed to be biding their time. For the next four hours, the demonstration remained in front of Parliament House, engaging in chanting and dance. ${ }^{108}$

Chicka Dixon exhorted student supporters to live up to their potential to be 'white brothers': 'if you are not going to be part of the problem, then you must be part of the solution'. 109 Kep Enderby told the protest that the police were not responsible for the repressive law which it was their duty to enforce, while a Builders' Labourers' Federation spokesperson criticised their willingness to obey orders. Aboriginal spokespersons emphasised the need for non-violence. A book ${ }^{110}$ was circulated among the participants, who signed it while police 'kept moving the deadline. ${ }^{111}$ Sykes, and others involved in the third occupation of the lawns, regarded this as 'a real coup de grace'.

By three o'clock, no police intervention had occurred other than a further extended deadline for removal of the tent. The police then informed the demonstrators that they could 'march back with full honour', ${ }^{112}$ and the majority of the students returned to the university, having made their presence felt in support of the embassy and Aboriginal land rights at a comparatively festive event.

At this juncture, Hal Wootten (who had remained on the edge of the crowd throughout the proceedings) passed a note from the Aboriginal protesters to the police to the effect that the Aboriginal demonstrators would allow 'two unarmed police' to enter the crowd (still numbering well over one hundred) and dismantle the tent. Gordon Briscoe accompanied Wootten to reassure the police of the good intentions of the protesters, and (although 'suspicious') they accepted this offer. ${ }^{113}$

At half past three, those who remained heeded Chicka Dixon's call to 'sit there peacefully ... just allow them to come in'. Seven police officers ${ }^{114}$ were led through the crowd by Osborne. There were some calls of 'boo', but no physical resistance to the removal of the tent.

A few moments later, however, the protesters had:

congregated over the other side of the park ... we had a piece of canvas and held it up over our heads and they looked across and thought we had put the tent up again ... they came running across to tear the tent down and found it was just a whole lot of people standing up holding a piece of canvas on their heads. 115

107 Woroni (ANU student newspaper), 1972.

108 Ningla-A-Na, directed by Alessandro Cavadini, 1972.

109 Harris 1972, p. 10

110 If extant, this visitors' book (and many other leaflets and personal reflections) would certainly make a valuable source for an autonomous history of the embassy by an Aboriginal author. Although Kevin Gilbert, James Miller and Dr Roberta B. Sykes have all referred to these events in their publications, no major history of these events has been written by a participant or Aboriginal author.

111 Dr Roberta Sykes, interview, 18 October 1991.

112 Jack Waterford, interview, 30 July 1991

113 Hal Wootten, personal recollections of the Aboriginal Embassy, 23 November 1992 (in possession of the author).

114 Woroni, 31 July 1972 . Obviously a larger delegation than expected.

115 Dr Roberta Sykes, interview, 18 October 1991. 
The police, after exchanging 'murmurs and glances', ${ }^{116}$ removed the canvas to reveal a circle of Aboriginal people sitting smiling at them, making the then-popular raised V-sign of peace, and holding aloft a placard designating the site as the Aboriginal Embassy. 117 Some of the protesters picked up the canvas again and followed the police back across the roads, dropping it at their feet.

At the close of the day, there had been no violence. Instead, there had been a day of symbolic, non-violent and creative action. The primacy of this approach since the inception of the protest, combined with restraint on both sides, prevented a violent confrontation. Some participants considered that the police had been told to 'stand off'; in fact, as R.A. Wilson recalled the third removal of the embassy, 'the government and the minister left it entirely to my discretion', 18 but there is no evidence of any governmental decision to this effect. The organisation of the protest, the calm orchestration of the actual point of contact by Chicka Dixon, ${ }^{119}$ and the negotiations undertaken by Wootten and Briscoe were essential contributing factors which made the ascendancy of non-violence possible. A spontaneous adoption of non-violent action amidst the jubilation of strength in numbers occurred, although this approach owed much to the symbolic nature of the protest over the preceding months.

In the months that followed, the embassy remained a significant issue in Aboriginal and mainstream politics. Howson's conference of State and Territory Advisory Councils was disrupted by activists using symbolic methods of protest, and adopted a firm stance on land rights. ${ }^{120}$ The conference also resolved to re-erect the embassy for a fourth time, and this in fact occurred on 12 September when Justice Blackburn declared that 'the ordinance was not notified in accordance with the provisions of the Act:. ${ }^{21}$ This in itself wrought temporary havoc with the legal system, making dozens of other associated ordinances invalid. In both Houses of Parliament, intense debate took place over the government's inept handling of the affair, and former government minister Jim Killen ${ }^{122}$ crossed the floor to vote with the opposition over the re-gazettal of the ordinance. Whitlam called the fourth and final protest - removed without violence on the morning of the thirteenth - 'an assertion of the rights and dignity of the Australian Aborigines'.123

The embassy was, in many ways, a success story. ${ }^{124}$ Although not necessarily an election issue, the embassy highlighted the failings of the government on the eve of Whitlam's victory in November 1972. The embassy assumed a mythology of historical and political significance amongst Aboriginal people. Despite the fact that its central demand for land rights was only partially fulfilled by the Northern Territory act of $1976,{ }^{125}$ the longevity of the demand for the return of land in other areas (that is, in areas outside those covered by the recent native title legislation) and more generally for Aboriginal

116 Woroni, 31 July 1972.

117 Ningla-A-Na, directed by Alessandro Cavadini, 1972.

118 R.A. Wilson, interview, 16 August 1991.

119 Michael Anderson, interview, 28 August and 10 November 1991.

120 Among other protests, Aboriginal activists stuffed their mouths with white paper gags to indicate their lack of equal speaking rights. See New Dawn, October 1972.

121 Federal Law Reports.

122 Now the Hon. Sir James Killen.

123 Australia, House of Representatives 1972, Debates, vol. HR80, p. 1218.

124 Ralph Hunt himself conceded that the protest achieved a 'token' victory (interview, 16 October 1991). Authors such as Adam Shoemaker (1989) and Hannah Middleton (1977) are perhaps unaware of the influence of the protest and the longevity of its renown. Aboriginal Land Rights (NT) Act, 1976. 


\section{THE ABORIGINAL EMBASSY}

sovereignty ${ }^{126}$ indicates its pivotal significance in the history of contemporary Aboriginal politics.

The embassy exemplified the efficacy of protest action within the framework of Australian democracy. ${ }^{127}$ Gary Foley called the July demonstrations a 'spectacular moral victory ... an enormous psychological boost for the movement', and even advocates of other, violent methods of direct action shared in the euphoria of making a powerful media image, exposing the inadequacy of the government, and placing land rights on the political agenda for the following two decades. Had violence escalated, as it could well have done in July, the legend and the legacy of the protests would be essentially different to the status and achievements of the Aboriginal Embassy.

\section{LIST OF REFERENCES}

Clark, C.M.H. 1980, A Short History of Australia, New York.

Coombs, H.C. 1978, Kulinma, Canberra.

Dexter, Barrie n.d., Unpublished and untitled manuscript in possession of the author.

Gilbert, Kevin 1973, Because a White Man'll Never Do It, Sydney.

Goodall, Heather 1990, 'Land in our own country: The Aboriginal movement in south east Australia, 1860-1914', Aboriginal History, vol. 14, nos 1 and 2, pp. 1-24.

Harris, Stewart 1972, This Our Land, Canberra.

Hasluck, Paul 1988, Shades of Darkness: Aboriginal Affairs, 1925-1965, Melbourne.

Howson, Peter 1984, The Howson Diaries: The Life of Politics, ed. Don Aitkin, Ringwood.

Hunt, R.J. n.d., Reflections on the Aboriginal 'Tent Embassies', unpublished manuscript in possession of the author.

McMahon, William 1972, Australian Aborigines: Commonwealth policy and achievements, unpublished Prime Ministerial statement in possession of the author.

McNally, Ward 1973, Goodbye Dreamtime, Canterbury,

Middleton, Hannah 1977, But Now We Want the Land Back: A History of the Australian Aboriginal People, Sydney.

Morris, Barry 1985, 'Cultural domination and domestic dependence: the Dhan-Ghadi and the protection of the state', Canberra Anthropology, vol. 8, nos 1 and 2, pp. 87-116.

Read, Peter 1990, Charles Perkins: A Biography, Ringwood.

Reynolds, Henry 1990, With the White People, Ringwood.

Shoemaker, Adam 1989, Black Words, White Page: Aboriginal Literature 1929.1988, Brisbane.

Sykes, Roberta 1989, Black Majority, Hawthorn.

Turner, A. (ed.) 1975, Black Power in Australia, Melbourne.

126 As well as accumulating legendary status, the embassy was the model for further encampments on the lawns of the (old) Parliament House in 1974, 1979, and 1992. The latter incarnation of the embassy remains in place at the time of writing, demanding the recognition of Aboriginal sovereignty.

127 Other encampments of a political nature, such as the major protests against uranium mining in 1983, and later protest against US bases, became common on the lawns of Parliament House in the years after the Aboriginal Embassy. 